\title{
Woody Species Composition, Diversity, and Recovery Six Years after Wind Disturbance and Salvage Logging of a Southern Appalachian Forest
}

\author{
Callie A. Oldfield * and Chris J. Peterson \\ Department of Plant Biology, University of Georgia, Athens, GA 30602, USA; cjpete@uga.edu \\ * Correspondence: callieoldfield@uga.edu
}

Received: 31 December 2018; Accepted: 1 February 2019; Published: 6 February 2019

\begin{abstract}
Salvage logging after wind disturbance of a mixed conifer-hardwood forest results in sapling compositional changes but no changes to species diversity six years post-disturbance. Several conceptual frameworks allow for predictions of the effects of forest disturbances on composition, but fewer yield predictions of species diversity. Following compound disturbance, tree species diversity and composition is predicted to shift to early successional species. Because of the greater cumulative severity, diversity should be lower in areas experiencing windthrow + salvage logging than in similar sites experiencing windthrow alone. We examined the effects of wind disturbance and salvage logging on diversity parameters over six years. We hypothesized that the effects of salvage logging on diversity would be short-lived, but that species composition would be altered six years post-disturbance. Sampling plots were established in a mixed-hardwood forest in north Georgia, USA, after a 2011 EF3 tornado and surveyed in 2012 and 2017. Nineteen $20 \times 20 \mathrm{~m}$ plots were surveyed (10 unsalvaged, 9 salvaged) for parameters including Shannon diversity, species richness, and composition. Ordinations were used to visualize tree and sapling species composition in salvage logged plots. We found that there was no significant difference in Shannon diversity between salvaged and unsalvaged plots before disturbance, $<1$ post-disturbance, or 6 years post-disturbance. The disturbances altered the tree and sapling species compositions, with salvaged plots having more mid-successional saplings but few true pioneer species. There appears to be an emerging pattern in the wind disturbance + salvaging literature which our study supports- salvaging does not affect tree species diversity but shifts species composition over time.
\end{abstract}

Keywords: windthrow; tornado; tree species; disturbance severity; tree regeneration; salvaging; salvage logging; succession

\section{Introduction}

While our understanding of individual disturbance effects in forests is well-established, knowledge of and ideas about compounded disturbances (multiple events in a short period of time) is still developing [1,2]. Natural disturbances such as wind, fire or drought may interact in ways that suggest the combined effects can be understood in light of the cumulative severity [3,4]. Forests are a patchwork of previous disturbances with different stages of recovery. There may be many overlapping natural disturbances in a forest-and these can interact with one another to increase severity $[5,6]$. The amplifying effects of such interactions can lead to ecological tipping points, which when reached, can permanently change aspects of a community, including its function and composition [5,7].

Wind is the most common agent of disturbance in mesic temperate forests and affects thousands of square kilometers annually $[1,8,9]$. The immediate effects of a windthrow may include tree mortality, changes in the size structure, and reduced species diversity of affected sites $[8,10]$. Less well-known is 
how wind may interact with anthropogenic disturbances, such as wind followed by salvage logging of damaged and downed trees [11-13]. We test whether salvage logging compounds the effects of wind disturbance, using a tornado damaged forest that was partially salvage logged.

Several conceptual frameworks can provide expectations of trends in composition, diversity and successional state after wind disturbance and salvage logging. The intermediate disturbance hypothesis (IDH) posits that local species diversity will be highest when disturbance frequency, size, or severity is intermediate due to increased dominance by pioneer (ruderal) species during regeneration as disturbance severity increases [14]. Therefore, under the framework of the intermediate disturbance hypothesis, we expect species composition in wind disturbance + salvaged logged sites to exhibit higher relative abundance of pioneer species compared to wind disturbance alone. Regarding species diversity, the IDH would predict highest diversity following wind damage alone (generally considered a moderate severity event [3]), and lower diversity following wind + salvage, because the combined severity of the two events (sensu [4]) is quite high.

Roberts' $[15,16]$ model of disturbance severity provides predictions based on three axes describing the percent damage to the canopy, understory, and forest floor [15]. For instance, a wind disturbance of moderate severity would have moderate canopy removal, limited understory removal, and limited soil disruption, but when combined with salvage logging, would have greater canopy removal, greater understory removal, and greater soil disruption [16]. The Roberts model predicts the more severe the disturbance is on multiple axes, the greater proportion of regeneration will derive from long distance dispersal and regeneration from the seed bank (i.e., pioneer species). The Roberts model, however, does not yield predictions of species diversity.

The cusp catastrophe model $[3,17]$ provides a framework to explain compositional change as a result of disturbance severity and neighborhood effects. In this framework, 'heavy windthrow' alone is considered of moderate severity, implying that windthrow + salvaging would be a high severity combination. Combined with the classification of mixed oak forests as neutral to negative in terms of neighborhood effects, this model predicts a steadily increasing shift to earlier-successional species composition following disturbance combinations of increasing severity but does not make explicit predictions about diversity.

Distinct from expectations derived from the above concepts, numerous empirical studies fuel a vigorous, ongoing controversy over the extent to which post-disturbance salvage logging may be ecologically detrimental (e.g., [18]). Several prominent reviews [19-22] emphasize detrimental effects of salvaging, such as soil compaction, injury to surviving trees, crushing of seedlings and advance regeneration, and altered biogeochemical cycles and trace gas fluxes. For example, Donato et al. [23] reported that post-fire salvaging hindered regeneration in conifer forests of Oregon, while Lindenmayer and Ough [24] found similar effects after fire in eucalypt forests of Australia.

In a potential counterpoint, research into effects of salvaging after wind disturbance often-but not always-finds no detrimental effects. On one hand, Rumbaitis del Rio [25], studying herbaceous layer vegetation, found windthrow + salvage to lower species richness, species diversity, and total cover, as well as tree seedling density, compared to windthrow alone. Most other studies, however, report no difference or higher diversity, basal area, stem density, or size structure [26-29]; the few studies that span more than a decade of recovery show that initial seemingly detrimental salvaging effects are often transitory [11,30,31]. Thorn et al. [12] presents a comprehensive meta-analysis on the effects of salvage logging on different taxonomic groups, concluding that it alters species composition, but not species diversity. Of the studies in the meta-analysis, nearly $75 \%$ presented results from five years or fewer after the disturbance. Several studies sampled from situations that did not allow separation of blowdown effects from salvaging effects, but nevertheless found broadly similar patterns [32-34].

Despite the scarcity of detrimental salvaging effects on diversity after wind disturbance, a clear trend in many studies is a shift to an earlier-successional species composition of regeneration when wind is followed by salvaging (e.g., [26-30]), whereas wind disturbance alone often advances the successional state of woody vegetation. 
Given the above, we hypothesized that (1) species diversity would decrease immediately after the windthrow and diversity would be even lower in sites that experienced salvage logging. Six years post-disturbance, however, we expect diversity to be indistinguishable between salvage logged and windthrown sites; (2) Species composition will differ between salvage logged and windthrown sites, with salvage logged sites dominated by early successional species.

\section{Materials and Methods}

\subsection{Site Background}

In April 2011, an EF3 tornado [35], blew through Northeast Georgia [1]. This tornado affected 5629 hectares (ha) of forest, with $18 \%$ of the affected area experiencing a damage severity of over $50 \%$ tree basal area felled [1]. To examine the effects of this tornado on tree composition, we established sampling plots within the Chattachoochee-Oconee National Forest (34.698 N, $-83.886 \mathrm{~W})$. The elevation at the site ranged from 588-672 $\mathrm{m}$ asl. The secondary forests are mixed hardwood, dominated by Quercus spp., Carya spp., Tsuga canadensis (eastern hemlock), Oxydendron arboreum (sourwood), Pinus strobus (white pine), and Acer rubrum (red maple). According to the USDA Web Soil Survey [36], the soils in this area are fine-loamy, mixed, mesic humic Hapludults (Tusquitee, Edneyville, and Porters loams). Temperature ranges seasonally from $3.9-22.8^{\circ} \mathrm{C}$, and annual precipitation is $1580 \mathrm{~mm}$ [37].

\subsection{Plot Establishment}

In July-September 2011, and March-June 2012, $3620 \times 20 \mathrm{~m}$ plots were established in tornado damaged areas, and trees surveyed before salvage logging. Plots were established in transects of tornado damage on north and south facing slopes, with half of the plots planned to be salvaged. All trees over $10 \mathrm{~cm}$ diameter at breast height $(\mathrm{DBH})$ were surveyed within each plot. For the purposes of this manuscript, each time DBH is mentioned, its units of measurement will be in $\mathrm{cm}$. Trees killed by the tornado were distinguished from previously dead trees so that tornado severity could be calculated. Salvage operations were carried out from mid-2012 through 2013. The spatial extent of the salvage logging was unpredictable, and plots were revisited to determine whether salvaging had occurred. In 2017, 19 plots were relocated and tree DBH and sapling density were recorded. Of those plots, 9 were salvaged, and 10 were unsalvaged. In 2017, saplings, defined as trees $>2 \mathrm{~m}$ tall and up to $10 \mathrm{~cm}$ $\mathrm{DBH}$, were measured in four $2 \times 2 \mathrm{~m}$ quadrats at each cardinal direction in each plot. Some permanent plots were not included in the 2017 survey due to difficulty of locating plot corner markers, as plots were marked before salvaging.

\subsection{Comparison of Plots before Tornado or Salvaging}

Using the 2012 data, the pre-disturbance structure, diversity, and species composition could be assessed before the tornado by 'resurrecting' trees killed in the disturbance.

For the purposes of this study, 2012 pre-disturbance (before both tornado and salvage) plots will be labeled as either 'pre-disturbance, unsalvaged' or 'pre-disturbance, salvage' to indicate that they have not yet experienced wind disturbance or salvaging but have been separated based on whether they will be salvaged in the future. All sampling in 2012 was post-tornado, pre-salvage. By the time of the 2017 sampling, 6 years had elapsed since wind disturbance and 4-5 years since salvaging. In the 2017 data, the two types of plots are defined as 'post-tornado, post-salvaging' or 'post-tornado, unsalvaged'. We use the terms $<1$ and 6 years post-disturbance refer to the time since the wind disturbance, as the salvage logging took place in the years after the wind disturbance.

\subsection{Data Analysis Comparing Salvaged Plots with Unsalvaged Plots}

To characterize regeneration of woody vegetation, we calculated measures of diversity and size class distribution. We used Welch's $t$-tests and two-way ANOVAs to determine whether there was a 
difference in the means of diversity and size class parameters between the years and salvage conditions. Mean values are reported \pm standard deviation. We also visualized the basal area $\left(\mathrm{m}^{2} \mathrm{ha}{ }^{-1}\right)$ of tree and sapling species (2017 only) in pre-tornado pre-salvage, pre-tornado unsalvage, and post-tornado post-salvage and post-tornado post unsalvaged areas as a whole.

Non-metric multidimensional scaling (nMDS) was performed on tree species compositions in salvaged $(n=9)$ and unsalvaged $(n=10)$ plots in 2012 and 2017 using $R$ [38] and package vegan [39]. Specifically, pre-tornado pre-salvage, pre-tornado unsalvage, and post-tornado salvage and post-tornado unsalvaged plots were compared, and ordinal hulls were generated.

\section{Results}

\subsection{Tornado Severity}

The mean tornado severity, here defined as relative basal area loss, for salvaged and unsalvaged plots was $0.64 \pm 0.28$. Salvaged and unsalvaged plots did not differ in tornado severity ( $t$-test; $p=0.58$; Figure 1 ).
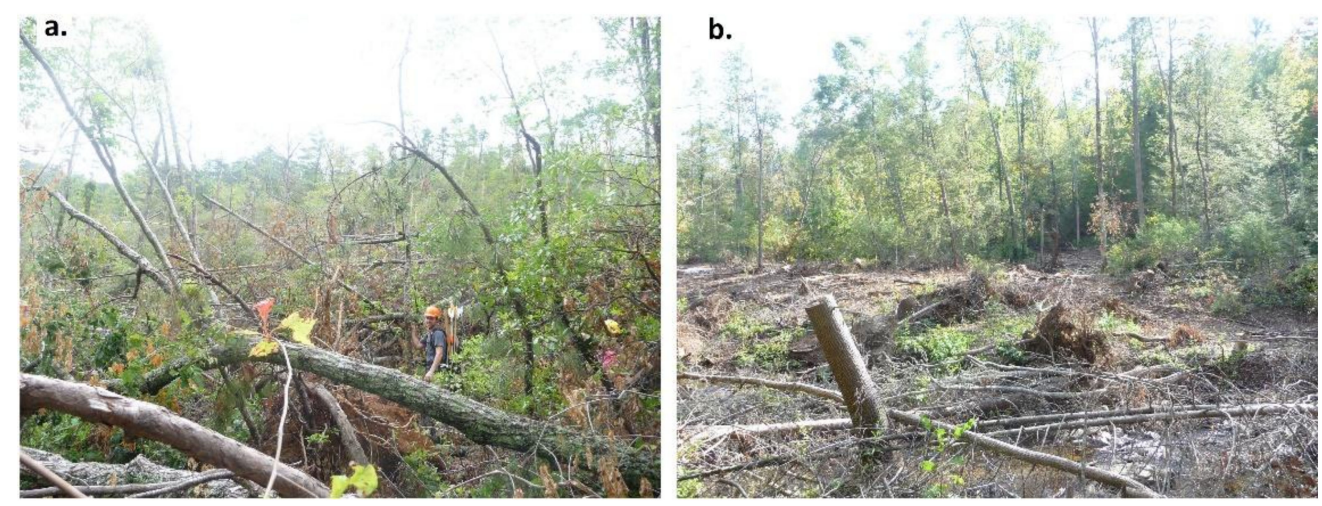

Figure 1. A study site in the Chattahoochee-Oconee National Forest shortly after the 2011 windthrow (a), and after salvage logging (b).

\subsection{Tree Diversity, Density, and Basal Area before, $<1$ Year, and 6 Years after Windthrow and Salvage Logging}

Table 1 shows the trajectory of tree diversity pre-disturbance, $<1$ year post-tornado and pre-salvage logging, and 6 years post-tornado and post-salvage logging (Table 1). Shannon diversity decreased in the one-year to six-year post-disturbance time interval. There were 439 individuals sampled pre-disturbance, compared to 281 individuals surviving the wind disturbance. Six years post-disturbance, 252 surviving individuals were sampled in the same plots.

At the plot scale, pre-tornado, pre-salvaging Shannon diversity for trees was $1.93 \pm 0.24$ in plots that would later be salvaged, compared to $1.81 \pm 0.25$ for plots that would remain unsalvaged. Shannon diversity did not differ between plots before experiencing disturbance ( $t$-test; $p=0.31$ ).

Six years post-tornado and post-salvaging, surviving trees in salvaged plots had a mean Shannon Diversity of $1.29 \pm 0.39$, and those in unsalvaged plots had a mean diversity of $1.39 \pm 0.35$. An ANOVA examining the effects of condition (salvage or unsalvage), year, and their interaction on Shannon diversity indicated that year was significant $(\mathrm{F}=24.92, p<0.001)$. Condition $(\mathrm{F}=0.017, p=0.90)$ and the interaction of condition and year were insignificant $(\mathrm{F}=1.073, p=0.31)$.

Species richness decreased immediately after the disturbance but increased to pre-disturbance levels after six years. An ANOVA examining the effects of condition (salvage or unsalvage), year, and their interaction on species richness indicated that year was significant $(\mathrm{F}=27.62 ; p<0.001)$. Condition $(\mathrm{F}=0.28$, $p=0.60)$ and the interaction of condition and year was insignificant $(\mathrm{F}=1.30, p=0.26)$.

Stem density and basal area showed similar patterns as Shannon diversity, with year being the only significant factor in an ANOVA examining the effects of condition (salvage or unsalvage), year, and their interaction on the dependent variable. For stem density, year was significant $(\mathrm{F}=12.75$, 
$p=0.001)$, and condition $(\mathrm{F}=0.92, p=0.34)$ and the interaction of condition and year were insignificant $(\mathrm{F}=0.97, p=0.33)$.

Table 1. Shannon diversity, total stems, basal area, and species richness for pre-tornado, $<1$ year post-tornado, and 6 years post-tornado salvaged and unsalvaged plots ( \pm Standard Deviation) of the remaining stand

\begin{tabular}{cccc}
\hline Tree Metrics & $\begin{array}{c}\text { Pre-Tornado, } \\
\text { Pre-Salvage }\end{array}$ & $\begin{array}{c}<1 \text { y Post-Tornado, } \\
\text { Post-Salvage }\end{array}$ & $\begin{array}{c}\text { 6 y Post-Tornado, } \\
\text { Post-Salvage }\end{array}$ \\
\hline Shannon & & & \\
\hline Salvage & $1.93(0.24)$ & $1.62(0.19)$ & $1.29(0.39)$ \\
Unsalvage & $1.81(0.25)$ & $1.54(0.34)$ & $1.39(0.35)$ \\
\hline Total stems (per ha) & & & \\
\hline Salvage & $650.0(140.25)$ & $377.75(130.75)$ & $330.50(232.0)$ \\
Unsalvage & $515.0(151.75)$ & $362.50(167.25)$ & $332.50(242.0)$ \\
\hline Basal area (m ${ }^{2} /$ ha) & & & $12.0(7.25)$ \\
\hline Salvage & $33.75(9.0)$ & $14.0(9.0)$ & $22.5(27.5)$ \\
Unsalvage & $42.75(14.25)$ & $27.0(14.25)$ & \\
\hline Species richness & & & $9.87(1.64)$ \\
\hline Salvage & $9.22(1.56)$ & $6.66(1.58)$ & $9.20(2.15)$ \\
\hline Unsalvage & $7.90(2.02)$ & $6.30(2.40)$ &
\end{tabular}

\subsection{Tree Size Class Distributions}

The mean pre-disturbance DBH of trees in unsalvaged plots was $28.7 \pm 1.3$, whereas the mean DBH of trees in pre-tornado, pre-salvaged plots was $22.9 \pm 0.74$. Trees had a significantly lower mean $\mathrm{DBH}$ in plots that would be later salvaged ( $t$-test; $p=0.0015)$. Most of that difference in pre-disturbance size structure was due to much greater stem abundances in the smallest size class $(10-20 \mathrm{~cm} \mathrm{DBH}$; Figure 2a), in the plots that would later be salvaged.

The mean DBH six years after disturbance in salvaged plots was $19.4 \pm 3.63$, compared to the mean DBH of post-tornado, unsalvaged plots $(25.5 \pm 7.0)$. The average DBH was significantly higher for unsalvaged plots ( $t$-test; $p=0.037$ ). Unsalvaged plots have a tail of individuals with a large $\mathrm{DBH}$, whereas the largest individual in a salvaged plot has a DBH in the $40-49.9 \mathrm{~cm}$ DBH category (Figure 2b). 
a. 400
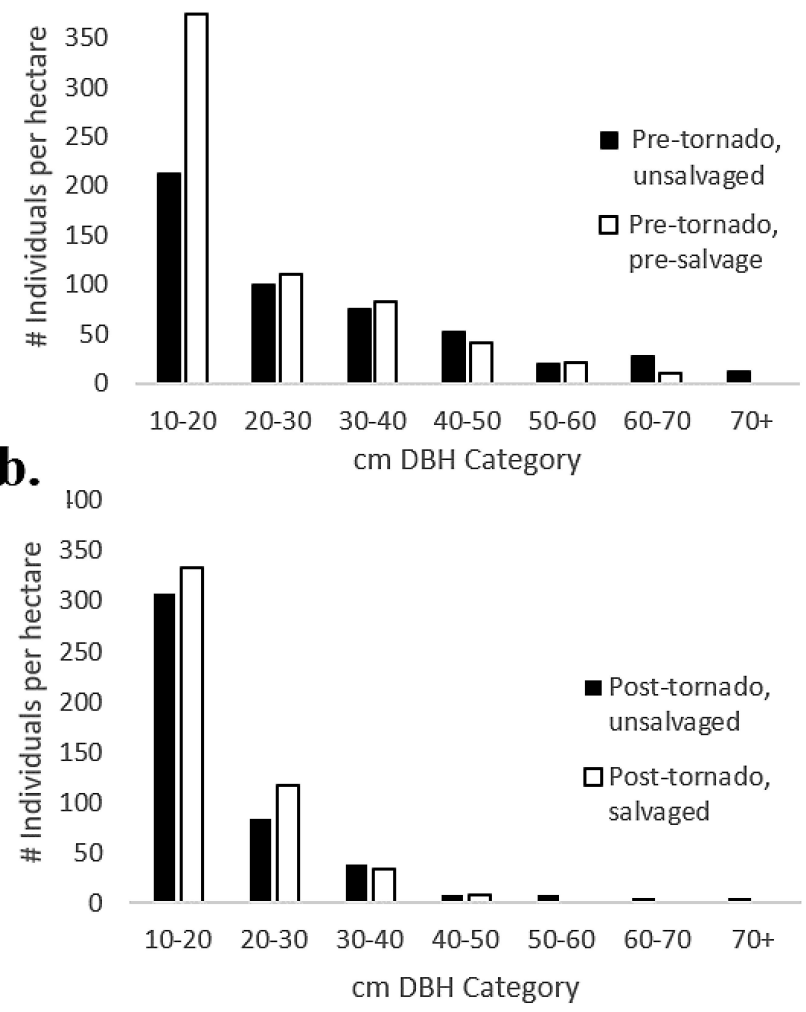

Figure 2. Frequency distributions among size ( $\mathrm{cm}$ DBH) classes pre-tornado (a) and six years post-tornado (b) for salvaged and unsalvaged plots.

\subsection{Tree Species Composition Ordinations}

The final run of the nMDS had a stress of 0.24 (linear fit $=0.669$; non-metric fit $=0.941$ ). Prior to the tornado, species composition broadly overlapped between the plots that would be salvaged and those that would not. After the tornado, salvaged plots cluster away from the pre-disturbance plots, but overlap with the post-tornado, unsalvaged ordinal hull (Figure 3).

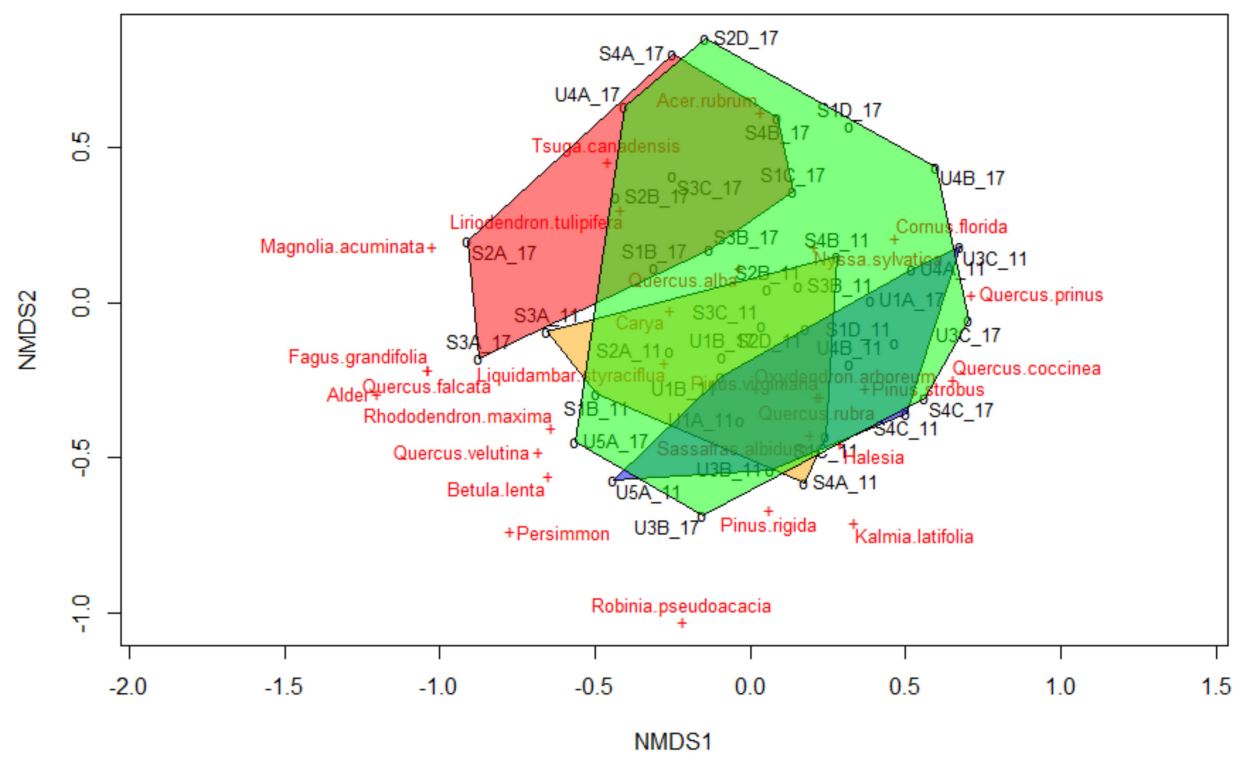

Figure 3. NMDS for trees pre-tornado, pre-salvage (orange); pre-tornado, unsalvaged (blue); six years post-tornado, post-salvage (red); and six years post-tornado, unsalvaged (green) plots. 


\subsection{Sapling Diversity and Density Parameters Six Years after Wind Disturbance and Salvage Logging}

For saplings, 2017 Shannon diversity in salvaged and unsalvaged plots was $0.96 \pm 0.48$ and $1.32 \pm 0.41$, respectively; this difference was not statistically significant $(t$-test; $p=0.11)$. The total number of sapling species found in all unsalvaged plots was 18, compared to 17 for salvaged plots. A total of 201 saplings were sampled.

There was no significant Pearson correlation between plot basal area and sapling density in 2017 (Figure 4). For salvaged plots, the correlation coefficient was $-0.11(t=-0.29, \mathrm{dF}=7, p=0.78)$. For unsalvaged plots, the correlation coefficient was $-0.51(t=-1.67, \mathrm{dF}=8, p=0.14)$. There were no apparent relationships between sapling species composition, basal area, and condition.

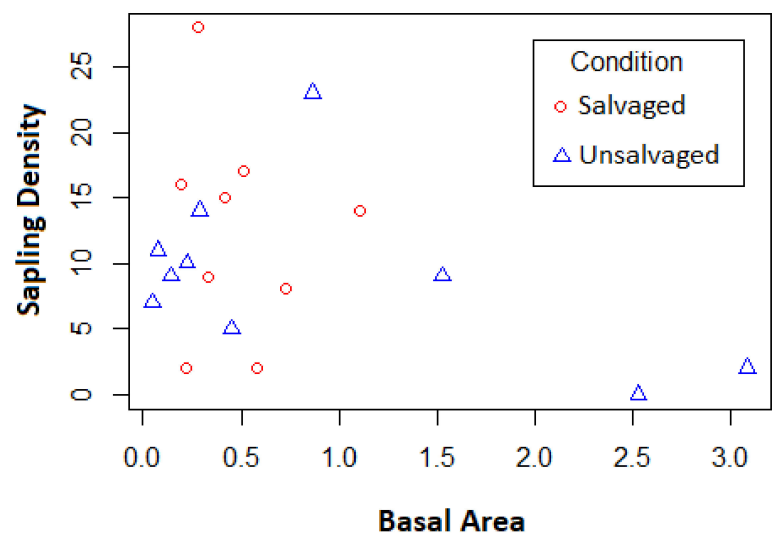

Figure 4. Scatterplot of plot $\left(400 \mathrm{~m}^{2}\right)$ surviving tree basal areas vs sapling density in 2017 by condition. Salvaged plots had a Pearson's correlation of $-0.11(p=0.78)$. Unsalvaged plots had a Pearson's correlation of $-0.51(p=0.14)$.

\subsection{Sapling Ordination}

The nMDS for saplings in 2017 had a stress of 0.15 (linear fit $=0.871$; non-metric fit $=0.979$ ). Salvaged and unsalvaged plots separated in ordinal space, indicating different compositions (Figure 5). According to the nMDS, salvaged plots tended to have more Acer rubrum and Pinus strobus, while unsalvaged plots tended to have more Sassafras albidum and Kamlia latifolia. Early-successional species such as Lirodendron tulipifera or Robinia pseudoacacia were surprisingly rare.

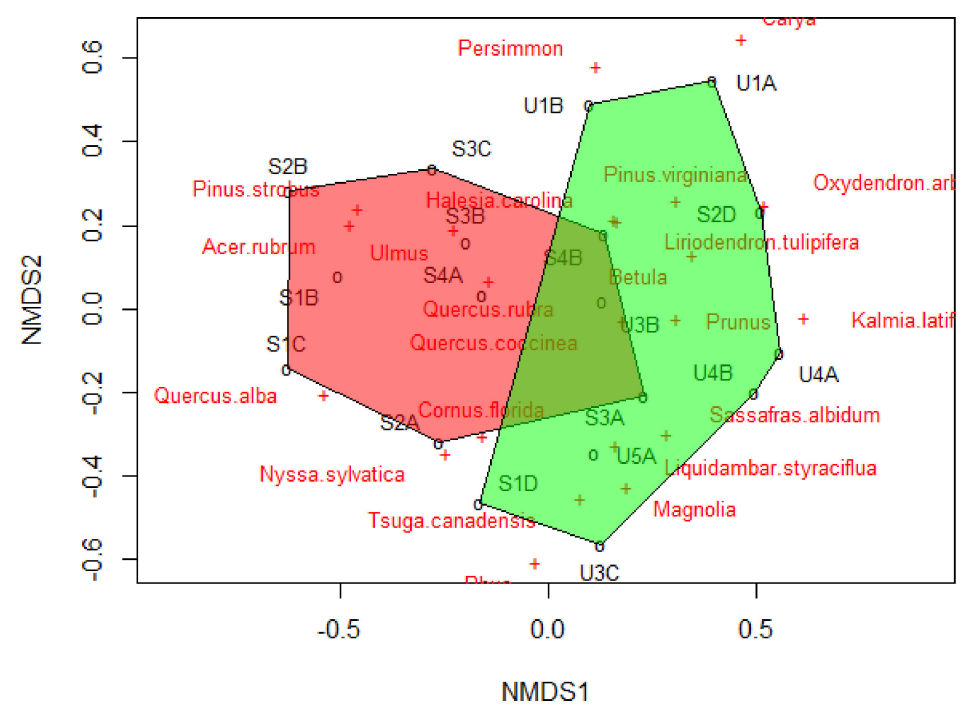

Figure 5. Non-metric multidimensional scaling (nMDS) of saplings in plots after tornado and salvage logging. Salvaged plots are indicated in red, and unsalvaged plots are green. 


\subsection{Sapling Species Accumulation Curve}

Species accumulation curves showed that not only were more total species observed in unsalvaged plots (7), but that the curve for unsalvaged plots ascended more steeply (Figure 6).

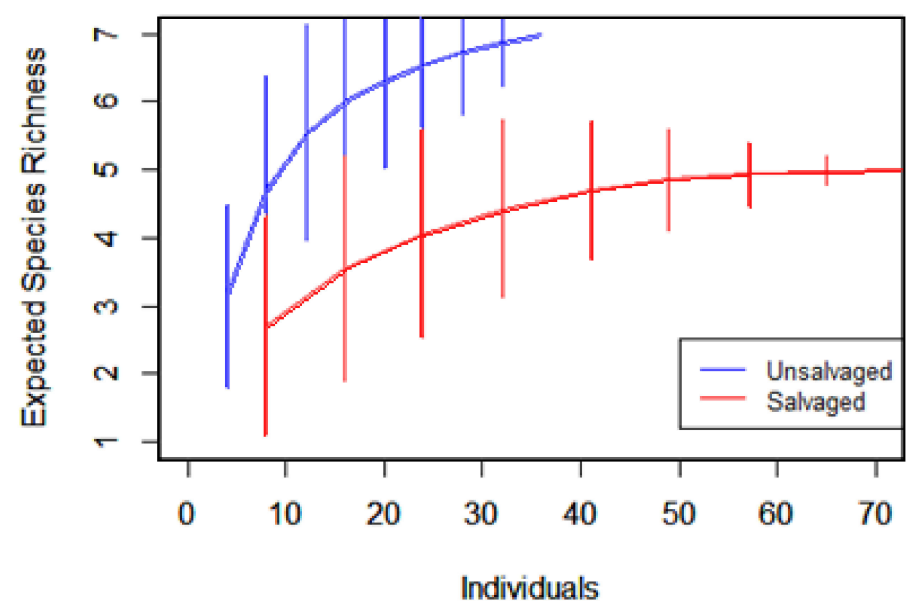

Figure 6. Species accumulation curve based on individual saplings in salvaged (red) and unsalvaged (blue) plots six years post-disturbance.

\subsection{Tree and Sapling Species Basal Area Comparison}

Combining 2017 basal area of saplings and trees (both pre-disturbance survivors and post-disturbance recruits) reveals that the species diversity and dominance in the four conditions as a whole are similar, with the exception of P. strobus, which is largely missing in the post-tornado post-salvage plots (Figure 7). While species that represented a small amount of basal area were grouped in the 'Other species' category, the total number of species for each condition were as follows: pre-tornado pre-salvage (22), pre-tornado unsalvaged (19), post-tornado post-salvage (24), post-tornado unsalvaged (26).

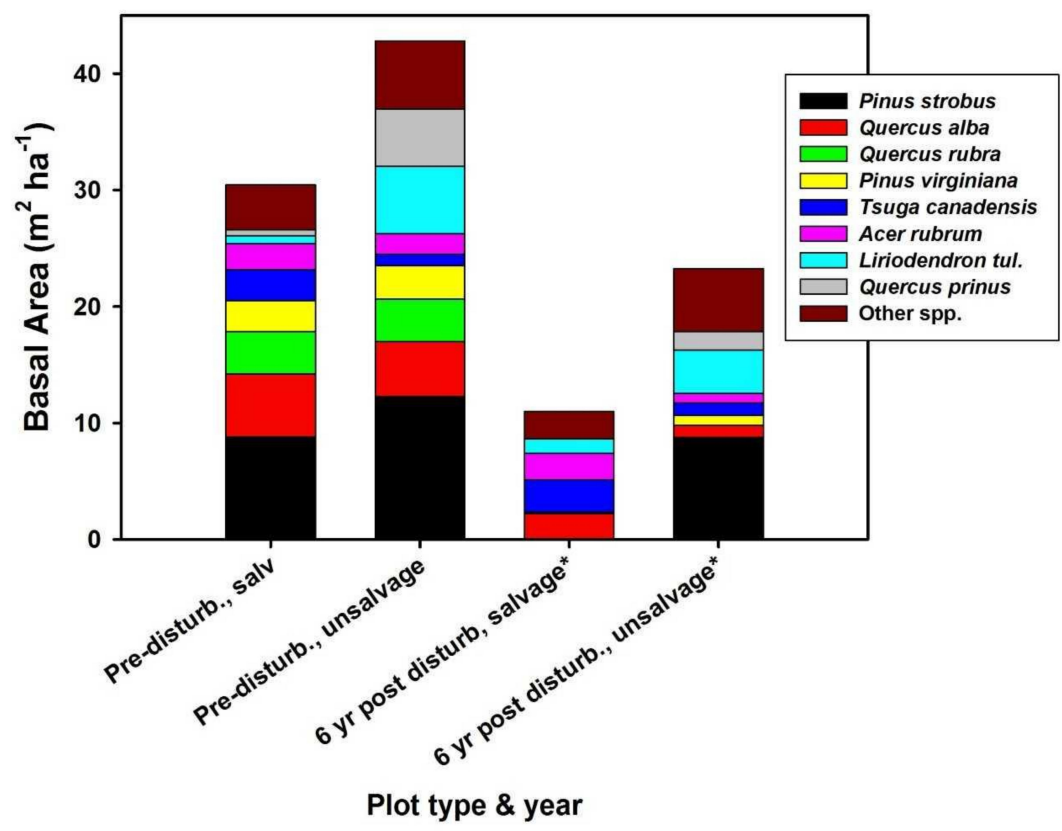

Figure 7. Stacked bars show the basal area $\left(\mathrm{m}^{2} \mathrm{ha}^{-1}\right)$ per species per disturbance condition: pre-tornado pre-salvage, pre-tornado unsalvaged, post-tornado post-salvage, and post-tornado unsalvaged. Saplings were included in the post-tornado (2017) results $\left.{ }^{*}\right)$. 


\section{Discussion}

This study examined the effect of salvage logging on tree and sapling diversity, tree size structure, and sapling community composition. Our sampling allows a comparison of pre-disturbance, $<1$ year post-disturbance, and 6 years post-disturbance, a rarity for salvage logging studies [12]. Furthermore, although most conceptual frameworks relevant to compound disturbance research focus on multiple natural disturbances, such ideas must be confronted with findings from combined natural and anthropogenic disturbances. Wind followed by salvaging is an especially common natural + anthropogenic combination, and our findings add to the growing list of wind + salvage studies (e.g., [40]). Though the windthrow's destructive nature altered the tree size structure, the differences in size structure between plot types (salvaged and unsalvaged) remained consistent with the pattern found before the windthrow-plots that were unsalvaged continued to have a higher DBH than plots that were salvaged. However, an examination of the distribution of individuals in each size class shows that the drivers of these patterns have changed-before the windthrow, plots that would later be salvaged had more trees in the 10-20 cm DBH category. After the windthrow, this pattern was driven by the lack of large $(>50 \mathrm{~cm}$ DBH) trees in salvaged plots. This pattern of tree size structure in salvaged vs. unsalvaged plots indicates the salvage logging operation removed large still-living trees, which were still present in the unsalvaged plots. We noted that there were fallen but still living trees six years post-windthrow in the unsalvaged plots ( $\mathrm{CAO}$, field observation). Therefore, when considering the effects of salvage logging, it is important to consider that trees that are standing or with minor damage may also be salvaged due to their size and value. This may have a counterproductive effect if encouraging a diverse, heterogenous forest is a management goal.

In partial support of our hypothesis, salvaged plots had greater abundance of mid-successional species (including P. strobus) when compared to unsalvaged plots, but very few pioneer species. It is possible that this is caused by the heterogeneous environment that resulted from the salvaging machinery. Of the salvaged plots, only one was directly located in the skid trails of the salvaging operation. Given the soil compaction and disturbance, we may expect, and did visually observe, more pioneer species in these skid trails outside of the plots. These findings are similar to those reported by Peterson and Leach [4], Nelson et al. [29], and Fidej et al. [41]. Therefore, the heterogeneous nature of salvage logging may result in modest overall impacts due to large areas that are lightly impacted, and small areas that are heavily impacted (e.g., by the skid trails) (c.f. [11]). Supporting this notion, Nelson et al. [29] found that tree diversity metrics did not differ overall between post-windthrow salvaged and unsalvaged plots over three years. However, these researchers found that pioneer species were more abundant in areas of high severity soil disturbance caused by the salvage logging.

These results provide support to the idea that salvage logging does not negatively impact species diversity, but that disturbance severity may affect species composition. Sapling community composition diverged in salvaged plots compared to unsalvaged plots. We found more mid-successional sapling species in salvaged plots, such as $P$. strobus and A. rubrum, whereas unsalvaged plots were characterized more by later successional species such as $T$. canadensis, Kalmia latifolia and Carya species. This may be a function of the increased soil disturbance and greater light availability as seen by reduced basal area in salvaged plots compared to unsalvaged. These results provide support to the Thorn et al. [12] meta-analysis that, broadly, salvage logging after a natural disturbance changes community composition but not diversity parameters even 6 years post-disturbance. In a Tennessee windthrow and subsequent salvage logging study, tree seedling diversity did not differ two years after disturbance [27]. The authors concluded that the disturbance and its interaction may not have been sufficiently severe to result in a lasting difference, but greater disturbance severity led to greater tree species composition change. Compared to Peterson and Leach [27] the present study characterized a more severe wind disturbance over a longer period of time, but we did not detect a difference in sapling diversity as a result of salvage logging. Royo et al. [11] found that salvage logging had effects on sapling diversity for the first several years after disturbance, 
but these effects were ephemeral. However, the authors determined that the soil disturbance caused by salvaging resulted in sapling compositional differences even five years after disturbance. These results are consistent with our own findings.

When examining the four conditions (pre-tornado pre-salvage and unsalvage, post-tornado salvage and unsalvage), we found that the relative dominances of species was consistent over time, with the exception of $P$. strobus. The most dominant species pre-tornado, its basal area decreased in the post-tornado post-salvage plots when compared to the unsalvaged plots. We believe that this further adds to the point made by our frequency diagrams that salvage logging affects trees that are both large and valuable, even if they are still standing or relatively undamaged. Therefore, in addition to the many $P$. strobus trees were killed by the windthrow, it is likely that living trees were also removed from the site through salvage logging. Another difference in species richness is apparent when examining the conditions as a whole: pre-tornado pre-salvage had a combined (tree + sapling) species richness of 22, while six years after the disturbance the same plots had a species richness of 24, an increase of 2 species. The pre-tornado unsalvaged area had a species richness of 19 , but that increased to 26 six years after disturbance. The increase of seven species in unsalvaged plots compared to an increase of two species in salvaged plots suggests that salvage logging limit the accumulation of species, although the overall trend was not enough to cause 2017 diversity to differ between salvaged and unsalvaged plots.

It seems that this study, though spanning six years, is still too early to produce firm conclusions on the future canopy tree compositional changes caused by wind disturbance and salvage logging. Even six years post-disturbance, tree diversity, tree basal area, and total tree stems were lower than at $<1$ year post-disturbance, displaying the lag effect [42]. When we examined sapling density compared to surviving basal area, a metric to assess damage severity (Figure 3), we found that the pattern for unsalvaged plots resembles the bell shaped curve as predicted by the intermediate disturbance hypothesis [16]. The salvaged plots, which represent a combined disturbance, had a lower basal area overall and no apparent relationship between basal area and sapling density. However, despite expectations based on the IDH that sapling species diversity would be higher in unsalvaged (winthrow alone) than salvaged (two cumulative disturbances), there was only a small and nonsignificant trend towards more species in the unsalvaged plots. Our examination of sapling species composition six years post-disturbance showed only modest effects of disturbance on successional status of the sapling layer, as predicted by the cusp catastrophe model and Roberts model [3,15-17]. Interestingly, a study that examined sapling regeneration at 10 and 20 years post-disturbance found that site factors ( $\mathrm{pH}$ and ground cover) and not disturbance type (windthrow or windthrow + salvage) controlled regeneration and sapling density [43]. Both salvaged and unsalvaged plots contained late successional species, but salvaged plots had greater abundance of mid-successional Pinus strobus and Acer rubrum. This partially supports the expectations of compositional change but falls short of the expected major compositional shift to pioneer species in salvaged areas.

The data available do not allow us to discern whether the saplings in our 2017 sample were composed of released advance regeneration or new recruits. Long-term Harvard Forest studies that examined the effects of a simulated hurricane found that recovery was initially comprised of sprouting from damaged trees and new seedlings, but the longer term ( $>20$ years) patterns of composition were driven by surviving trees and release of trees already present pre-disturbance $[44,45]$.

\section{Conclusions}

As this study and others have shown, it is crucial to monitor the impacts of combined disturbances $>5$ years post-disturbance. Ephemeral effects of salvage logging may be detected in the first years immediately after the disturbance, but they may be poor indicators of longer-term successional trajectories. Moreover, this study adds to a growing set of multi-year studies that consistently find roughly predictable effects of salvaging after wind disturbance but few examples of diversity reduction. 
Author Contributions: Conceptualization, C.O. and C.P; Methodology, C.P.; Software, C.P.; Validation, C.O. and C.P.; Formal analysis, C.O.; Investigation, C.O; Resources, C.P.; Data curation, C.O.; Writing-original draft preparation, C.O.; Writing-review and editing, C.O. and C.P.; Visualization, C.O. and C.P.; Supervision, C.P.; Project administration, C.P.; Funding acquisition, C.O. and C.P.

Funding: This research was funded by the National Science Foundation grants AGS-1141926 from Physical and Dynamic Meteorology and DEB-1143511 from Population and Community Ecology; NSF Graduate Research Fellowship Program, University of Georgia Graduate School, University of Georgia Department of Plant Biology through the Palfrey Award, Haines Family Field Botany Award, and Graduate Student Association Award.

Acknowledgments: We thank our field assistants who make this work possible: Rhett Parr, Ajay Patel, John Howard, Kathryn Thompson, and Sydney Mai. We thank the graduate students that began this project in 2012: Luke Snyder and Kaysandra Waldron, with assistance from Eli White, Trevor Sprague, Meredith Barrett, and Patrick Johnson. We are grateful for the insightful comments by Jacquelin Mohan, Daniel Markewitz, Doug Aubrey, and Chris Gough.

Conflicts of Interest: The authors declare no conflict of interest.

\section{References}

1. Cannon, J.B.; Hepinstall-Cymerman, J.; Godfrey, C.M.; Peterson, C.J. Landscape-scale characteristics of forest tornado damage in mountainous terrain. Landsc. Ecol. 2016, 31, 2097-2114. [CrossRef]

2. Paine, R.T.; Tegner, M.J.; Johnson, E.A. Compounded perturbations yield ecological surprises. Ecosystems 1998, 1, 535-545. [CrossRef]

3. Frelich, L.E. Forest Dynamics and Disturbance Regimes: Studies from Evergreen-Deciduous Forests; Cambridge University Press: Cambridge, UK, 2002.

4. Peterson, C.J.; Leach, A.D. Salvage logging after windthrow alters microsite diversity, abundance and environment, but not vegetation. Forestry 2008, 81, 361-376. [CrossRef]

5. Reyer, C.P.O.; Brouwers, N.; Rammig, A.; Brook, B.W.; Epila, J.; Grant, R.F.; Holmgren, M.; Langerwisch, F.; Leuzinger, S.; Lucht, W.; et al. Forest resilience and tipping points at different spatio-temporal scales: Approaches and challenges. J. Ecol. 2015, 103, 5-15. [CrossRef]

6. Williams, C.A.; Gu, H.; MacLean, R.; Masek, J.G.; Collatz, G.J. Disturbance and the carbon balance of US forests: A quantitative review of impacts from harvests, fires, insects, and droughts. Glob. Planet. Change 2016, 143, 66-80. [CrossRef]

7. Romme, W.H.; Everham, E.M.; Frelich, L.E.; Moritz, M.A.; Sparks, R.E. Are Large, infrequent disturbances qualitatively different from small, frequent disturbances? Ecosystems 1998, 1, 524-534. [CrossRef]

8. Everham, E.M.; Brokaw, N.V.L. Forest damage and recovery from catastrophic wind. Bot. Rev. 1996, 62, 113-185. [CrossRef]

9. Webb, S.L. Disturbance by wind in temperate-zone forests. In Ecosystems of Disturbed Ground; Walker, L.R., Ed.; Elsevier: Amsterdam, The Netherland, 1999; pp. 187-222.

10. Mitchell, S.J. Wind as a natural disturbance agent in forests: A synthesis. Forestry 2013, 86, 147-157. [CrossRef]

11. Royo, A.A.; Peterson, C.J.; Stanovick, J.S.; Carson, W.P. Evaluating the ecological impacts of salvage logging: Can natural and anthropogenic disturbances promote coexistence? Ecology 2016, 97, 1566-1582. [CrossRef]

12. Thorn, S.; Bässler, C.; Brandl, R.; Burton, P.J.; Cahall, R.; Campbell, J.L.; Castro, J.; Choi, C.Y.; Cobb, T.; Donato, D.C.; et al. Impacts of salvage logging on biodiversity: A meta-analysis. J. Appl. Ecol. 2018, 55, 279-289. [CrossRef]

13. Lindenmayer, D.B.; Noss, R.F. Salvage logging, ecosystem processes, and biodiversity conservation. Conserv. Biol. 2006, 20, 949-958. [CrossRef] [PubMed]

14. Connell, J.H. Diversity in tropical rain forests and coral reefs. Science 1978, 199, 1302-1310. [CrossRef] [PubMed]

15. Roberts, M.R. A conceptual model to characterize disturbance severity in forest harvests. For. Ecol. Manage. 2007, 242, 58-64. [CrossRef]

16. Roberts, M.R. Response of the herbaceous layer to natural disturbance in North American forests. Can. J. Bot. 2004, 82, 1273-1283. [CrossRef]

17. Frelich, L.E.; Reich, P.B. Neighborhood effects, disturbance severity, and community stability in forests. Ecosystems 1999, 2, 151-166. [CrossRef] 
18. DellaSala, D.A.; Karr, J.R.; Schoennagel, T.; Perry, D.; Noss, R.F.; Lindenmayer, D.B.; Beschta, R.L.; Hutto, R.L.; Swanson, M.E.; Evans, J. Post-fire logging debate ignores many issues. Science 2006, 312, 1137-1137. [CrossRef] [PubMed]

19. McIver, J.D.; Starr, L. A literature review on the environmental effects of postfire logging. West. J. Appl. For. 2001, 16, 159-168.

20. Beschta, R.L.; Rhodes, J.J.; Kauffman, J.B.; Gresswell, R.E.; Minshall, G.W.; Karr, J.R.; Perry, D.A.; Hauer, F.R.; Frissell, C.A. Postfire management on forested public lands of the Western United States. (Special section: Wildfire and conservation in the western United States.). Conserv. Biol. 2004, 18, 957-967. [CrossRef]

21. Foster, D.R.; Orwig, D.A. Preemptive and salvage harvesting of New England forests: When doing nothing is a viable alternative. Conserv. Biol. 2006, 20, 959-970. [CrossRef]

22. Lindenmayer, D.B.; Foster, D.R.; Franklin, J.F.; Hunter, M.L.; Noss, R.F.; Schmiegelow, F.A.; Perry, D. Salvage harvesting policies after natural disturbance. Science 2004, 303, 1303. [CrossRef]

23. Donato, D.C.; Fontaine, J.B.; Campbell, J.L.; Robinsin, W.D.; Kauffman, J.B.; Law, B.E. Post-wildfire logging hinders regeneration and increases fire risk. Science 2006, 311, 352. [CrossRef] [PubMed]

24. Lindenmayer, D.B.; Ough, K. Salvage logging in the montane ash eucalypt forests of the Central Highlands of Victoria and its potential impacts on biodiversity. Conserv. Biol. 2006, 20, 1005-1015. [CrossRef] [PubMed]

25. Rumbaitis del Rio, C.M. Changes in understory composition following catastrophic windthrow and salvage logging in a subalpine forest ecosystem. Can. J. For. Res. 2006, 36, 2943-2954. [CrossRef]

26. Lain, E.J.; Haney, A.; Burris, J.M.; Burton, J. Response of vegetation and birds to severe wind disturbance and salvage logging in a southern boreal forest. For. Ecol. Manage. 2008, 256, 863-871. [CrossRef]

27. Peterson, C.J.; Leach, A.D. Limited salvage logging effects on forest regeneration after moderate-severity windthrow. Ecol. Appl. 2008, 18, 407-420. [CrossRef] [PubMed]

28. Fischer, A.; Fischer, H.S. Individual-based analysis of tree establishment and forest stand development within 25 years after wind throw. Eur. J. For. Res. 2012, 131, 493-501. [CrossRef]

29. Nelson, J.L.; Groninger, J.W.; Battaglia, L.L.; Ruffner, C.M. Bottomland hardwood forest recovery following tornado disturbance and salvage logging. For. Ecol. Manage. 2008, 256, 388-395. [CrossRef]

30. Palik, B.; Kastendick, D. Woody plant regeneration after blowdown, salvage logging, and prescribed fire in a northern Minnesota forest. For. Ecol. Manage. 2009, 258, 1323-1330. [CrossRef]

31. Lang, K.D.; Schulte, L.A.; Guntenspergen, G.R. Windthrow and salvage logging in an old-growth hemlock-northern hardwoods forest. For. Ecol. Manage. 2009, 259, 56-64. [CrossRef]

32. Elliott, K.J.; Hitchcock, S.L.; Krueger, L. Vegetation response to large scale disturbance in a southern appalachian forest: Hurricane Opal and salvage logging. J. Torrey Bot. Soc. 2002, 129, 48-59. [CrossRef]

33. D'Amato, A.W.; Fraver, S.; Palik, B.J.; Bradford, J.B.; Patty, L. Singular and interactive effects of blowdown, salvage logging, and wildfire in sub-boreal pine systems. For. Ecol. Manage. 2011, 262, 2070-2078. [CrossRef]

34. Bottero, A.; Garbarino, M.; Long, J.N.; Motta, R. The interacting ecological effects of large-scale disturbances and salvage logging on montane spruce forest regeneration in the western European Alps. For. Ecol. Manage. 2013, 292, 19-28. [CrossRef]

35. McDonald, J.R.; Kishor, C.M. A Recommendation for an Enhanced Fujita Scale (EF-Scale); Wind Science and Engineering Center, Texas Tech University: Lubbock, TX, USA, 2006.

36. Web Soil Survey. Available online: https://websoilsurvey.sc.egov.usda.gov/ (accessed on 15 December 2018).

37. Diamond, H.J.; Karl, T.R.; Palecki, M.A.; Baker, C.B.; Bell, J.E.; Leeper, R.D.; Easterling, D.R.; Lawrimore, J.H.; Meyers, T.P.; Helfert, M.R.; et al. U.S. Climate reference network after one decade of operations status and assessment. Bull. Am. Meteorol. Soc. 2013, 94, 485-498. [CrossRef]

38. R Core Team. R: A Language and Environment for Statistical Computing; R Foundation for Statistical Computing: Vienna, Austria, 2017.

39. Oksanen, J.; Blanchet, F.G.; Kindt, R.; Legendre, P.; Minchin, P.R.; O’hara, R.B.; Simpson, G.L.; Solymos, P.; Stevens, M.H.; Wagner, H. Vegan: Community Ecology Package, R Package Version 2.5-2; 2018. Available online: https:/ /CRAN.R-project.org/package=vegan (accessed on 2 February 2019).

40. Elliott, K.J.; Swank, W.T. Long-term changes in forest composition and diversity following early logging (1919-1923) and the decline of American chestnut (Castanea dentata). Plant Ecol. 2008, 197, 155-172. [CrossRef] 
41. Fidej, G.; Rozman, A.; Nagel, T.A.; Dakskobler, I.; Diaci, J. Influence of salvage logging on forest recovery following intermediate severity canopy disturbances in mixed beech dominated forests of Slovenia. iForest-Biogeosci. For. 2016, 9, 430. [CrossRef]

42. Reich, P.B.; Bakken, P.; Carlson, D.; Frelich, L.E.; Friedman, S.K.; Reich, P.B.; Bakken, P.; Carlson, D.; Frelich, L.; Friedman, S.K.; et al. Influence of logging, fire, and forest type on biodiversity and productivity in southern boreal forests. Ecology 2001, 82, 2731-2748. [CrossRef]

43. Kramer, K.; Brang, P.; Bachofen, H.; Bugmann, H.; Wohlgemuth, T. Site factors are more important than salvage logging for tree regeneration after wind disturbance in Central European forests. For. Ecol. Manage. 2014, 331, 116-128. [CrossRef]

44. Plotkin, A.B.; Foster, D.; Carlson, J.; Magill, A. Survivors, not invaders, control forest development following simulated hurricane. Ecology 2013, 94, 414-423. [CrossRef] [PubMed]

45. Cooper-Ellis, S.; Foster, D.R.; Carlton, G.; Lezberg, A. Forest response to catastrophic wind: Results from an experimental hurricane. Ecology 1999, 80, 2683-2696. [CrossRef]

(C) 2019 by the authors. Licensee MDPI, Basel, Switzerland. This article is an open access article distributed under the terms and conditions of the Creative Commons Attribution (CC BY) license (http://creativecommons.org/licenses/by/4.0/). 